William R. DiPietro, $\mathrm{PhD}^{1}$

Daemen College, Amherst, New York, USA
ORIGINAL SCIENTIFIC ARTICLE

Received: February 26, 2015

Accepted: March 15, 2015

\title{
WAGES AND CORPORATE DOMINANCE
}

\begin{abstract}
As wages are the primary means of income for the majority of people in every country in the world, understanding the reasons for differences in wages is important for human welfare. One potential source of differences in wages between countries is differences in the degree of corporate dominance. This paper proposes that average country wages are negatively related to the extent of corporate dominance. The proposition is tested using cross country regression analysis. The results show that greater corporate dominance reduces average national wages when adjusting for the level of economic development and other relevant variables.
\end{abstract}

Key words: wages, corporate dominance, regression analysis

JEL classification: J310, L1

\section{ПЛАТЕ И КОРПОРАТИВНА ДОМИНАЦИЈА}

\section{Апстракт}

Пошто су плате главни извор прихода за већину људи у свакој земљи на свеmу, разумевање разлога за разлике у платама је важно за људску добробит. Један од потенцијалних извора разлика у платама између земаља је разлика у степену корпоративне доминације. У раду се претпоставља да су просечне плате негативно повезане са обимом корпоративне доминације. Претпоставка је тестирана помоћу регресионе анализе између земаља. Резултати показују да већа корпоративна доминачија смағује просечне начионалне зараде приликом прилагођавања нивоа економског развоја и других релевантних варијабли.

Кључне речи: плате, корпоративна доминација, регресиона анлиза

\section{Introduction}

With increasing globalization, corporate dominance of markets appears to be becoming greater and greater. Corporate dominance of product and labor markets, especially in the presence of weak and declining union strength and labor power, can be expected to lower wages and labor income on both an economic and political basis. Economically, monopolistic and monopolistic power, strictly from a neoclassical

\footnotetext{
${ }^{1}$ wdipietr@daemen.edu
} 
economics vantage point, tends to enhance profit's share of total economic income at the expense of labor's share. Politically, greater power in corporate hands, through increased corporate lobbying or other means, is apt to lead to undue corporate influence over politicians and, for that matter, over the entire political process. In general, greater corporate dominance of markets is apt to change political attitudes, dispositions, ideas, arguments, rationalizations, and even the political agendas themselves, making them more pro corporation and less concerned with labor issues, such as fair wages and adequate living standards for ordinary men and women. Greater corporate political influence tends to result in reduced corporate business regulation, even when the regulation is appropriate on equity and efficiency grounds, and to lax administration and enforcement of existing business regulations.

Economics is always concerned with incentives and for establishing and maintaining appropriate incentives systems-incentives systems that provide higher levels of economic efficiency, technological progress, and economic growth. For the effective operation of the private sector, self-interest needs to be aligned with social interest. The government needs to set the basic framework and the ground rules for this to occur. It has to have the desire and will to do so. Greater corporate dominance is likely to lead to greater and greater misalignment between corporate pursuit of profits and the welfare of society as a whole. It makes it more and more difficult for the government to bring the two into line, even under the assumption that government still wants to, and diminishes the government desire to do so.

The purpose of this paper is to quantitatively test the theoretical hypothesis that greater corporate dominance lowers wages, and, if the hypothesis proves to be correct, to get some feel for the magnitude of the effect.

The paper consists of five sections. The first section touches on some of the recent relevant literature with regard to wages. The second sections lay out a simple model of cross country wage determination with corporate dominance playing the central part or the key role. The third section discusses the sources of the measures of the various variables used in the actual empirical work. The fourth section presents and analyzes the results of cross country regressions of wages on corporate dominance. The fifth and final section rounds the paper out with some concluding comments and implications.

\section{Brief Literature Review}

Ivrendi, Guloglu and Yetkiner, hypothesize that divergence in factor endowment between countries is the source of differences in real wages between countries (Ivrendi, Guloglu \& Yetkiner, 2014). Employing a panel data set for twenty six OECD countries in their regression analysis, they find evidence that factor endowment in the form of productivity, capital, labor stock, together with human capital and unemployment, explain most of the variation in real wages in their sample, with each of the individual variables statistically significant and having their appropriate signs.

It may be the case that it is not differences in human skill, human capital that accounts for the bulk of variation in worker earnings that exists across countries, but rather diversity in rewards to skills (the price of skills). Using three wage sets of data on countries from around the world, Rosenzweig estimates skill prices for countries 
(Rosenzweig, 2010). He finds that skill prices differ markedly between countries, and that income inequality between countries is primarily due to different rewards for the same skills, and not due to differences in human capital as predicted by the neoclassical Mincer theory.

Hirsch reviews some of his and others past research on wages and wage determination in his 2007 presidential address to the Southern Economic Association (Hirsch, 2008). Although he maintains that the theory of one wage is the appropriate and useful starting point for looking at wages, it is heterogeneity in wages that he considers to be interesting to study and explain. He contends that differences in wages between cities and metropolitan areas are likely to disappear after adjusting for differences in cost of living and differences in amenities between different areas. He feels it is possible that government regulation in the product markets can lead to rent sharing with workers in industries with strong unions, as he believes occurred, at one point in time, in the trucking industry in the United States. For the U.S. as a whole, he finds that, although a large part of the variation in wage gaps can be explained by the standard neoclassical Mincer model, that the wage gaps unexplained by the standard neoclassical Mincer model may be even greater after adjusting for measuring errors, from, for example, such things as earnings imputations in the data.

Heinze and Wolf study the effect of competition, unionization, and workers councils, on the wage gap between men and woman within German firms (Heinze \& Wolf ,2010). Looking at a pooled sample of German firms ranging from 1148 to 1852 establishments for the years 1997-2004, their regressions show that relative firm size has a significant positive effect on the wage gap between men and women, after adjusting for human capital characteristics, that is to say, that reduced competition leads to a greater gender wage gap, while collective bargaining agreements and worker councils, on the other hand, decrease the gender wage gap.

Du Caju, Katay, Lamo, Nicolitsas, and Poelhekke investigate inter-industry wage differentials for eight European Union countries for 1995 and 2002 using data from the European Structure of Earnings Survey (Du Caju, Katay, Lamo, Nicolitsas, Poelhekke, 2010). Their data suggests that substantial inter-industry wage differentials still exist even after adjusting for workforce and job characteristics. These conditional interindustry wage differentials cannot be explained by unobserved quality differences in workers. However, they do appear to be determined by differences in the rents and rental sharing between industries, with the amount of rents depending on industry structure, and, the extent of rental sharing, depending on the collective bargaining strength of labor.

Du Caju, Rycx and Tojerow combine data from the Structure of Earnings Survey, that contains information on firm and individual characteristics, with the Structure of Business that contains firm financial information, to look at wages in Belgium for the years 1999-2005 (Du Caju, Rycx \& Tojerow, 2011). In their empirical analysis, they find that sizable wage differentials between sectors continue to exist after adjusting for numerous individual and firm characteristics, indicating that non- competitive forces are operating in wage determination; that firm's ability to pay, measured in terms of profits per worker, is a positive and significant factor for wages, suggesting that rent sharing between firms and workers may be one of the non-competitive aspects in wage determination; and that wage differentials between sectors still exist even after taking account of profits per worker of firms, suggesting that there are other dynamics operating to determine wages besides standard neoclassical forces and rental sharing. 
Fairris and Jonasson look for potential causes of intra-industry wage differences employing data on establishments from an original survey of several low wage industries in Los Angles for 2002 (Fairris \& Jonasson, 2008) . Using average establishment wages and occupational starting wages as alternative dependent variables, they run regressions on a sample of 190 establishments on a fairly sizable set of explanatory variables. Their regressions provide some evidence supporting a role for rental share and efficiency wages in explaining intra-industry wage differentials, but lend little support for the theory of compensating differences.

Freguglia and Menezes-Filho look at the sources for inter-regional wage differentials in Brazil using data between 1995 and 2002 (Freguglia \& Menezes-Filho, 2012). They find that most of the differentials between Brazilian states can be attributed to differences in the average ability of workers.

\section{Formalized Cross Country Wage Determination Model}

The model consists of one equation and a single partial derivative. The single equation model is as follows:

$$
\mathrm{W}=\mathrm{g}(\mathrm{D}, \mathrm{C}) \delta \mathrm{W} / \delta \mathrm{D}<0
$$

In the model $\mathrm{W}$ stands for average country wages, D stands for corporate market dominance, and $\mathrm{C}$ is a set other determinants of wages that act as control variables.

The model's focus is on corporate dominance as a potential determinant of wages. As shown by the negative partial derivative between wages and corporate dominance, it is theorized that wages are negatively related to corporate dominance, so that, an increase in corporate dominance is predicted to lead to a reduction in wages.

What has happened recently with the advance of globalization is the evolution of a new relationship between capital and labor that favors capital. Capital, especially concentrated capital, is acquiring more and more power. At one time, at least in the developed countries, when corporations were at most national in size and scope, there existed, with strong national unions, a fairly high level of countervailing power between capital and labor. Now, however, with capital, but not unions, successfully going international, and with the recent vogue in deregulation, free market ideology, and antiunion sentiment, this is no longer the case. The balance of power is becoming tilted more and more in favor of big business.

Besides corporate market dominance, three other variables are considered as potential determinants of wages across countries.

The first control variable, the first argument in the wage determination model other than corporate dominance, is the level of economic development. Wages are predicted to be positively related to the level of economic development. Standard neoclassical theory predicts that wages move in concert with labor productivity. The difference in labor productivity between the most highly developed countries and the least developed countries is enormous. Labor productivity is higher at higher levels of economic development for a large number of reasons. These include differences in the quantity and the quality of the physical and human capital stocks, and differences in the quantity and quality of infrastructure. 
The second control variable is government size. Wages are predicted to be positively related to the size of government for several reasons. First, the government is a source of employment. It employs substantial numbers of people in the military, in education, in the government bureaucracy itself, and in other areas. Second, the government is the primary funder of basic research. Basic research is the essential foundation for all research and development, and, research and development is the key driver of technological change and productivity improvement. Third, the government provides traditional public goods and services such as, infrastructure, law and order, educational systems, and defense that are necessary for the operation of an economy.

The third and final control variable is the share of country income going to research and development. Naturally, the greater the devotion, the greater the commitment, of society's resources to R\&D the higher wages are likely to be. Higher labor productivity spells higher wages. Investment in R\&D creates higher labor productivity, both in terms of building greater human capital among those engaged in $R \& D$, and, in terms the enhanced productivity that results from the products and services created through R\&D.

In sum, four variables are considered as potential determinants of wages. They are corporate dominance, the level of economic development, the size of the government, and the share of income going to R\&D. While corporate dominance, the key variable of interest is theoretically predicted to be negatively related to wages, the other three variables are expected to be positively related to wages.

\section{Data Sources for the Variables}

The average wages for countries are downloaded from Wikipedia (Wikipedia, 2014). Their source is the United Nation's International Labor Organization. The data are monthly average wages in purchasing power parity dollars for 2009.

The measure of the level of economic development is GDP per capita for 2010. The numbers come from the World Bank (World Bank, 2014).

Corporate dominance is quantified by adjusting the index of corporate dominance from 2009 through 2010 of the World Economic Forum so that higher values show greater corporate dominance (World Economic Forum, 2011). The World Economic forum's extent of market dominance index is based on answers to the survey question, "How would you characterize corporate activity in your country?". The range of possible answers are from one, dominated by a few business groups, to seven, spread among many firms. Given the World Economic Forum's corporate dominance index is inverted, for ease of understanding, the corporate dominance index used here is eight minus the World Economic Forum's corporate dominance index.

\section{The Empirical Results}

Table 1 shows the results of cross country regressions average wages on corporate market dominance and the three control variables. The table shows the results for four different regressions, one in which corporate dominance is the only explanatory variable, 
and three others in which corporate dominance is accompanied by one or more of the three control variables, namely, the level of economic development, the size of the government, and the share of $R \& D$ expenditure.

Table 1: Cross country regressions of average wages on corporate dominance and other variables

\begin{tabular}{|c|c|c|c|c|}
\hline & (1) & (2) & (3) & (4) \\
\hline CONSTANT & $\begin{array}{c}4656.11 \\
(11.03) \\
*\end{array}$ & $\begin{array}{c}2843.26 \\
(5.15) \\
*\end{array}$ & $\begin{array}{c}779.00 \\
(1.39)\end{array}$ & $\begin{array}{c}292.49 \\
(.63)\end{array}$ \\
\hline DOMINANCE & $\begin{array}{c}-764.64 \\
(-7.51) \\
*\end{array}$ & $\begin{array}{c}-450.17 \\
(-3.92) \\
*\end{array}$ & $\begin{array}{c}-314.18 \\
(-3.08) \\
*\end{array}$ & $\begin{array}{c}-169.78 \\
(-2.22) \\
* *\end{array}$ \\
\hline GDPPC & & $\begin{array}{c}.0215 \\
(4.45) \\
*\end{array}$ & $\begin{array}{c}.0225 \\
(5.79) \\
*\end{array}$ & $\begin{array}{c}.0389 \\
(9.72) \\
*\end{array}$ \\
\hline GOVTTOGDP & & & $\begin{array}{c}85.97 \\
(6.04) \\
*\end{array}$ & $\begin{array}{c}47.03 \\
(3.71) \\
*\end{array}$ \\
\hline R\&DTOGDP & & & & $\begin{array}{c}167.29 \\
(2.65) \\
* *\end{array}$ \\
\hline RSQ & .453 & .574 & .729 & .893 \\
\hline $\mathrm{N}$ & 70 & 68 & 68 & 51 \\
\hline
\end{tabular}

The table is constructed in the following way. It is composed of five columns. The first column shows the potential explanatory variables, the set of variables eligible to enter the equations. The second, third, fourth, and fifth columns each show the results of a single regression equation. The equations are numbered in the first row. If and when a variable enters an equation, the top value in the body of the table corresponding to the row containing the variable and the column of the equation in which the variable enters is the estimated coefficient for that variable in that equation. The individual t-statistic, in parentheses, is right below the estimated coefficient. Variables that are significant at the one percent level of significance or better in an equation are marked with a single asterisk beneath the individual t-statistics. Those that are significant at the five percent level or better are labeled with two asterisks. The last two rows show, respectively, the R-squared values (RSQ), followed by the sample size $(\mathrm{N})$, the number of countries entering an equation.

The results support the idea that greater corporate dominance is detrimental to wages. The corporate dominance index (DOMINANCE) is negative and significant at the one percent level of significance or better in three of the four equations in table I (equations (1)-(3)), and is negative and significant at the five percent level of significance in the single remaining equation (equation (4)). Thus, whether corporate dominance is used alone as the sole explanatory variable, as in equation one, or in combination with the level of economic development and other explanatory variables, as in equations two, three, and four, corporate dominance has a negative and statistically significant effect on wages.

Furthermore, the magnitude of the impact of corporate dominance appears to be far from insubstantial. Looking at the estimated coefficient on corporate dominance in the 
fourth equation, the lowest estimated coefficient on corporate dominance for all the four equations in table 1, implies that a one point increase in corporate dominance, which can potentially vary between one and seven, leads to around a one hundred seventy dollar decrease in average wages in a country. If anything, the estimated coefficient in equation four probably understates the impact of corporate dominance on wages, as there may be some multicollinearity in equation four, with the direct effect of corporate dominance on wages being watered down by its potential indirect effect on wages working through corporate dominance's potential negative effect on R\&D expenditure.

The explanatory power of corporate dominance is also quite strong, especially for a cross section. When corporate dominance is used alone as an independent variable (Equation (1)), it explains over forty five percent of the total variation in average wages across countries, and, when combined with the other three variables (equation (4)), explains close to ninety percent of the cross country variation in average wages.

All of the other three variables also behave quite nicely. The measure of economic development, GDP per capita (GDPPC), just as theoretically expected, appears to be a positive force for wages. The variable is positive and significant at the one percent level or better in the three equations in which it appears (equations (2)-(4)).

The results suggest that the bigger government size is favorable for country wages. The government size variable (GOVTTOGDP) is positive and significant in equations three and four, the only two equations that it enters.

Lastly, the results show that research and development is a positive driver of wages. In equation four, the sole equation in which it appears, the percentage of R\&D expenditure to GDP (R\&DTOGDP) is positive and significant at the five percent level of significance.

\section{Conclusion}

Identifying a determinant of wages and its relationship with wages is of no small import. The level of wages really matters for the well-being of most members of society. Along with employment, adequate wages are necessary, are essential, for most members of a nation to attain a decent standard of living.

Wages constitute the mainstay of income for ordinary citizens, and can thus be viewed as the back bone or as the core component of national welfare.

The cross country empirical analysis of this paper strongly suggests that greater corporate dominance is associated with reduced wages for workers. Whether or not corporate dominance is used alone as the sole explanatory variable in a regression, or in regressions that control for other variables, corporate dominance proves to have a statistically consequential negative effect on wages.

The obvious policy implication of the analysis is that an important way by which a government can increase average wages in a country is to design policies that reduce corporate power and corporate dominance of markets. Markets need to be regulated so that corporations do not acquire large, unwarranted, market shares. Not only is this likely to be good for wages, but it probably will also be good for competition, and for economic efficiency. As small firms are often innovators and small firm growth is a major employment driver, it is also likely to be favorable for employment and technical progress. 


\section{References}

Behr, A. \& Potter, U. (2010). What Determines Wage Differentials across the EU?. The Journal of Economic Inequality, 8(1), 101-120. http://epunet.essex.ac.uk/Conf2006/ papers/Poetter_Behr_paper.pdf, July 15, 2014.

Du Caju, P., Rycx, F. \& Tojerow, I. (2011). Inter-Industry Wage Differentials: How Much Does Rent Sharing Matter?. The Manchester School, 79(4), 691-717.

Du Caju, P., Katay, G., Lamo, A., Nicolitsas, D. \& Poelhekke, S. (2010). Inter-Industry Wage Differentials in EU countries: What Do Cross Country Time Varying Data Add to the Picture?. European Central Bank working paper, No. 1182. http://www.ecb. europa.eu/pub/pdf/scpwps/ecbwp1182.pdf, July 17, 2010.

Fairris, D. \& Jonasson, E. (2008). What Accounts for Intra-industry Wage Differentials? Results from a Survey of Establishments. Journal of Economic Issues, 42(1), 97-113.

Freguglia, R. S. \& Naercio A. M.-F. (2012). Inter-Regional Wage Differentials with Individual Heterogeneity: Evidence from Brazil. The Annals of Regional Science, 49, 17-34.

http://link.springer.com/article/10.1007\%2Fs00168-010-0432-2\#page-1, July 23, 2014.

Heinze, A. \& Wolf, E. (2010). The Intra-Firm Gender Wage Gap: A New View on Wage Differentials based on Linked Employer-Employee Data. Journal of Population Economics, 23(3), 851-879. http://ftp.iza.org/dp3375.pdf, July 21, 2014.

Hirsch, B. T. (2008). Wage Gaps Large and Small. Southern Economic Journal, 74(4), 915-933.

Ivrendi, M., Guloglu, B. \& Yetkiner. H. (2014). The Neoclassical Determinants of Real Wage. Siyast, Ekonomi ve Yonetim Arasturmalari Dergisi, 2(2), 1-11. http:// siyasetekonomiyonetim.org/index.php/seyad/article/viewFile/116/112, July 16, 2014.

Lane, J., Laurie, I., Salmon, A. \& Spletzer, J. R. (2007). Establishment Wage Differentials. Monthly Labor Review, April 200, 1-15. http://www.bls.gov/opub/mlr/2007/04/ art1 full.pdf, July 17, 2014.

Rosenzweig, M. R. (2010). Global wage Inequality and the International Flow of Migrants. Economic growth Center, Yale University, discussion paper no. 983.

http://www.econ.yale.edu/growth_pdf/cdp983.pdf, July 22, 2014.

Wikipedia. (2014). List of Countries by Average Wages. http://en.wikipedia.org/wiki/ List_of_countries_by_average_wage, July 11, 2014.

World Bank. (2014). World Development Indicators, http://databank.worldbank.org/ data/views/variableSelection/selectvariables.aspx? source=world-developmentindicators, May 20, 2014.

World Economic Forum. (2011). The Global Competitiveness Report 2010-2011. http:// www3.weforum.org/docs/WEF_GlobalCompetitivenessReport_2010-11.pdf, June 20, 2014. 